\title{
DAKWAH \\ DAN DIMENSI AKULTURASI BUDAYA
}

\author{
Nunung Khoriyah *)
}

\begin{abstract}
Since its early spread, Islamic dakwah in Indonesia has shown its strong accommodation to local cultures that the arrival of Islam was not considered as a threat, but a companion which plays an important role in the cultural transformation. It shows that the character of Islam in Indonesia is accommodative to social tradition and cultures of the local people. This accommodative model was one of the characteristics of Indian mubaligh, which is then followed by Walisongo in their dakwah in Java. The dialogue process between Islam and social tradition was actualized in the mechanism of cultural process to face the local cultures. The combination between Islam and social cultures is a local interpretation to not make Islam too far from the real condition of the local people. Islam was not viewed as it was in Arab, but there should be a dialogue between Islam and the local cultures.
\end{abstract}

Keywords: Dakwah, Local Tradition, Acculturation, Cultural Dakwah, Walisongo.

\section{PENDAHULUAN}

Kondisi keagamaan kaum muslimin pada saat ini tidak dapat dipisahkan dari proses dakwah atau penyebaran Islam di Indonesia sejak beberapa abad sebelumnya. Ketika Islam masuk di Indonesia, kebudayaan Nusantara telah dipengaruhi oleh agama Hindu dan Budha, selain masih kuatnya berbagai kepercayaan tradisional, seperti animisme, dan dinamisme. ${ }^{1}$ Kebudayaan Islam akhirnya menjadi tradisi kecil di tengah-tengah Hinduisme dan Budhisme yang juga menjadi tradisi kecil. Tradisi-tradisi kecil inilah yang kemudian saling mempengaruhi dan mempertahankan eksistensinya.

Wilayah-wilayah Nusantara yang pertama tertarik masuk Islam adalah pusat-pusat perdagangan di kota-kota besar di daerah pesisir. Islam ortodok dapat masuk secara mendalam di kepulauan luar Jawa, yang hanya sedikit mendapat pengaruh Hindu dan Budha. Sementara itu, di Jawa,

") Dosen Fakultas Dakwah dan Komunikasi, UIN Syarif Hidayatullah Jakarta. 
Nunung Khoriyah: Dakwah dan Dimensi Akulturasi Budaya

agama Islam menghadapi resistensi dari Hinduisme dan Budhisme yang telah mapan. Dalam proses seperti ini, Islam tidak saja harus menjinakkan sasarannya, tapi juga harus memperjinak diri. ${ }^{2}$ Benturan dan resistensi dengan kebudayaan-kebudayaan setempat memaksa Islam untuk mendapatkan simbol yang selaras dengan kemampuan penangkapan kultural dari masyarakat setempat.

Kemampuan Islam untuk beradaptasi dengan budaya setempat memudahkan Islam masuk ke lapisan paling bawah dari masyarakat. Akibatnya, kebudayaan Islam sangat dipengaruhi oleh kebudayaan petani dan kebudayaan pedalaman sehingga kebudayaan Islam mengalami transformasi, bukan saja karena jarak geografis antara Arab dan Indonesia, tetapi juga karena ada jarak-jarak kultural.

Proses kompromi kebudayaan seperti ini tentu membawa resiko yang tidak sedikit karena dalam keadaan tertentu seringkali mentoleransi penafsiran yang agak menyimpang dari ajaran Islam murni. Kompromi kebudayaan ini pada akhirnya melahirkan sinkretisme atau Islam Abangan. Sementara itu, di pulau Lombok, hal itu dikenal dengan istilah Islam Wetu Telu. ${ }^{3}$

Islamisasi yang berlangsung di Nusantara pada dasarnya berada dalam proses akulturasi. Seperti telah diketahui bahwa Islam disebarkan ke Nusantara sebagai kaidah normatif di samping aspek seni budaya. Sementara itu, masyarakat dan budaya tempat Islam itu disosialisasikan adalah sebuah alam empiris. Dalam konteks ini, sebagai makhluk berakal, manusia pada dasarnya beragama dan dengan akalnya pula mereka paling mengetahui dunianya sendiri. Pada alur logika inilah, manusia melalui perilaku budayanya senantiasa meningkatkan aktualisasi diri. Oleh karena itu, dalam setiap akulturasi budaya, manusia membentuk, memanfaatkan, dan mengubah hal-hal agar sesuai dengan kebutuhannya. ${ }^{4}$

Dari paradigma inilah, masih dalam kerangka akulturasi, lahir sesuatu yang dikenal sebagai local genius. Local genius bisa diartikan sebagai kemampuan menyerap sambil mengadakan seleksi dan pengolahan aktif terhadap pengaruh kebudayaan asing sehingga dapat dicapai ciptaan baru yang unik, yang tidak terdapat di wilayah bangsa yang membawa pengaruh budayanya.

Pada sisi lain, secara implisit, local genius dapat dirinci karakteristiknya, yakni; mampu bertahan terhadap dunia luar, mempunyai kemamapuan megakomodasi unsur-unsur dunia luar; mempunyai kemampuan mengintegrasi unsur budaya luar ke dalam budaya asli, dan 
memiliki kemampuan mengendalikan dan memberikan arah pada perkembangan budaya selanjutnya. ${ }^{5}$

\section{PENGERTIAN DAKWAH}

Secara etimologis, kata 'dakwah' berarti 'ajakan', yang berasal dari kata Arab, da'â, yad'û, da'watan, du'a $a^{6}$ yang berarti mengajak, memanggil, menyeru, memanggil, permohonan dan mengharap manusia agar senantiasa berada di jalan Allah SWT. Istilah ini sering diberi arti yang sama dengan istilah tabligh, amar ma'ruf-nahi munkar, mauizhoh hasanah, tabsyir, inzhar, washiyah, tarbiah, ta'lim dan khotbah.

Pada tataran empirik, praktik dakwah harus mengandung tiga unsur, penyampai pesan, informasi yang disampaikan, dan penerima pesan. Namun demikian, dakwah secara terminologi mengandung pengertian yang lebih luas, yaitu sebagai aktivitas menyampaikan ajaran Islam, menyuruh berbuat baik, dan mencegah perbuatan mungkar, serta memberi kabar gembira dan peringatan bagi manusia.

Sebagai wacana praxis, dakwah selalu dikaitkan dengan frase 'dengan bijaksana', suatu ungkapan yang menegaskan penolakan atas setiap jalan kekerasan atau paksaan dalam mewujudkan tujuan. Pemaknaan etimologis ini diderivasi dari pemerian firman Allah SWT:

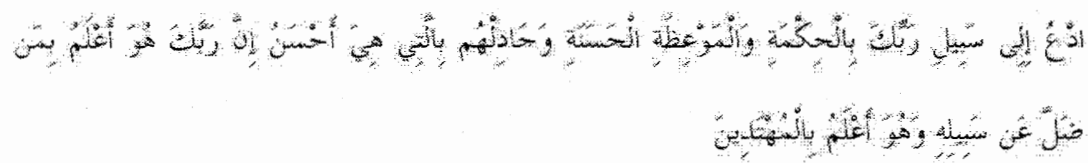

"Serulah (manusia) kepada jalan Tuhanmu dengan hikmah dan pelajaran yang baik dan bantahlah mereka dengan cara yang baik. Sesungguhnya Tuhanmu Dialah yang lebih mengetahui tentang siapa yang tersesat dari jalan-Nya dan Dialah yang lebih mengetahui orang-orang yang mendapat petunjuk" (Q.S. An-Nahl (16): 125)

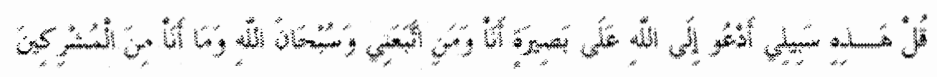

"Katakanlah: "Inilah jalan (agama) ku, aku dan orang-orang yang mengikutiku mengajak (kamu) kepada Allah dengan hujjah yang nyata, Maha Suci Allah, dan aku tiada termasuk orang-orang yang musyrik”. (Q.S. Yusuf (12): 108)

Berdasarkan penjelasan ayat tersebut, dapat disimpulkan bahwa dakwah pada dasarnya adalah upaya manusia dan untuk kepentingan manusia pula dalam kerangka mewujudkan nilai-nilai dasar keislaman dalam realitas kemanusiaan di mana kemaslahatan bagi semua. Nilai-nilai 
dimaksud adalah sesuatu yang lazim diistilahkan sebagai major themes of Islam, yakni ketuhanan (tawhîd), keadilan (al-'adâlah), egaliterianisme (al-musâwah), kebebasan (al-hurriyah), kebaikan (al-khayr), musyawarah (al-syûrâ), amr márûf nahiy munkar, dan seterusnya.

Makna dakwah sebagai seruan atau ajakan persuasif yang ramah itu relevan dengan metode dakwah yang dilansir Allah SWT sendiri dalam surat an-Nahl. Secara eksplisit, ayat tersebut mendiskripsikan tentang strategi metode dakwah, yaitu diperintah untuk "mengajak" manusia ke dalam jalan kebenaran dengan tiga cara, yaitu; (1) mengetengahkan alhikmah, (2) menyampaikan al-mawizhah al-hasanah (pelajaran yang baik), dan (3) melangsungkan mujâdalah (dialog) dengan cara terbaik.

\section{RELASI DAKWAH DAN BUDAYA LOKAL}

Budaya atau kebudayaan bersifat spesifik manusiawi. Ada manifestasi dan perwujudan dari segala aktivitas manusia sebagai upaya untuk memudahkan dan memenuhi kebutuhan hidupnya. Kebudayaan terdiri dari nilai dan simbol. Nilai-nilai budaya itu tidak kasat mata, sedangkan simbol budaya yang merupakan perwujudan nilai itulah yang kasat mata. Masjid, pasar, sekolah, rumah misalnya adalah perwujudan dari nilai-nilai budaya masyarakatnya. Setiap perwujudan aktivitas manusia, nilai-nilai budaya senantiasa hadir dan semua punya nilai budaya, walau terkadang tidak merupakan simbol budaya.

Dakwah adalah panggilan atau seruan bagi umat manusia menuju jalan Islam, yaitu jalan menuju Allah. Sebagai dinullah, Islam bersumber dari wahyu Allah SWT dan sunah Rasul-Nya, ia merupakan sumber nilai yang akan memberikan corak, warna dan bentuk kebudayaan Islam. Suatu bentuk kebudayaan yang berisikan pesan atau nilai-nilai Islami sekalipun akan muncul dari orang atau masyarakat bukan penganut dinul Islam. Demikian juga sebaliknya, tidak dikatakan budaya Islam, walau ia lahir dari orang atau masyarakat penganut dinul Islam, jika tidak memuat pesan atau nilai-nilai Islami. Pada hakikatnya, dakwah Islam merupakan aktualisasi imani (theologis) yang dimanifestasikan dalam suatu sistem kegiatan manusia beriman dalam bidang kemasyarakatan yang dilaksanakan secara teratur untuk mempengaruhi cara merasa, berfikir, bersikap dan bertindak manusia pada dataran kenyataan individual dan sosio-kultural dalam rangka mengusahakan terwujudnya ajaran Islam dalam semua segi kehidupan dengan menggunakan cara tertentu.

Dalam perspektif dakwah Islam, budaya atau kebudayaan adalah aktualisasi dari sikap tunduk (ibadah atau peribadatan) manusia kepada 
Allah. Salah satu analog yang menunjukkan simbol dan nilai budaya sebagai sikap tunduk pada Allah, sebagaimana firman-Nya:

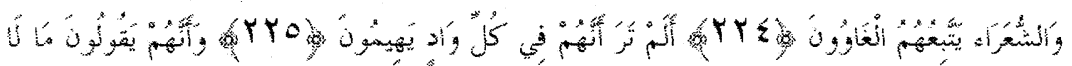

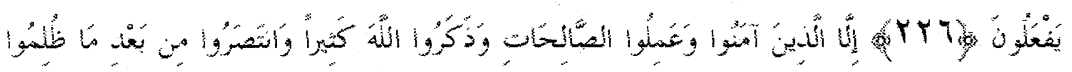

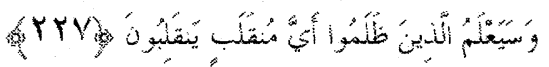

"Dan penyair-penyair itu diikuti oleh orang-orang yang sesat. Tidakkah kamu melihat bahwasanya mereka mengembara di tiap-tiap lembah, dan bahwasanya mereka suka mengatakan apa yang mereka sendiri tidak mengerjakan (nya)?, kecuali orang-orang (penyair-penyair) yang beriman dan beramal saleh dan banyak menyebut Allah dan mendapat kemenangan sesudah menderita kezaliman. Dan orang-orang yang zalim itu kelak akan mengetahui ke tempat mana mereka akan kembali”. (Q.S. Asy-Syua'ara (26): 224-227).

Ayat di atas menginformasikan bahwa ada dua jenis budaya yang diwakili oleh sosok pelakunya. Pertama, budaya yang dibangun dengan dimensi takwa yang diwakili oleh sosok pelaku budaya yang beriman, beramal shaleh, dan senantiasa berdzikir mengingat Allah serta sabar menghadapi kezaliman. Jika disepakati bahwa budaya itu spesifik manusiawi, maka pengaruh ideologi, pandangan hidup, sikap hidup, dan cara berpikir pelaku atau peletak budaya itu menjadi nilai dasar dari bentuk budaya tersebut. Seseorang yang memiliki kesalehan individual dan kesalehan sosial dalam dirinya, tentu akan melahirkan jenis budaya yang juga beroreintasi memudahkan jalan orang lain atau masyarakat untuk menjadi shaleh (al-Khair al-Ummah). Kedua, budaya yang dibangun dengan dimensi kesesatan dan kezhaliman. Seseorang yang berlatar belakang ideologi komunis atau kapitalis, misalnya, tentu juga akan menampilkan bentuk budaya dengan orientasi dan cara berpikir ideologi dimaksud dalam membangun tatanan masyarakatnya.

Selanjutnya, berkaitan dengan relasi antara Islam sebagai agama dengan budaya lokal, hal ini sangat jelas dalam kajian antropologi agama. Dalam perspektif ini, diyakini bahwa agama merupakan penjelmaan dari sistem budaya.7 Berdasarkan teori ini, Islam sebagai agama samawi dianggap merupakan penjelmaan dari sistem budaya suatu masyarakat Muslim. Tesis ini kemudian dikembangkan pada aspek-aspek ajaran Islam, termasuk aspek hukumnya. Para pakar antropologi dan sosiologi mendekati hukum Islam sebagai sebuah institusi kebudayaan Muslim. Pada konteks sekarang, pengkajian hukum dengan pendekatan sosiologis dan 
antrologis sudah dikembangkan oleh para ahli hukum Islam yang peduli terhadap nasib syari'ah. Dalam pandangan mereka, jika syari'ah tidak didekati secara sosio-historis, maka yang terjadi adalah pembakuan terhadap norma syariah yang sejatinya bersifat dinamis dan mengakomodasi perubahan masyarakat. ${ }^{8}$

Islam sebagai agama, kebudayaan, dan peradaban besar dunia sudah sejak awal masuk ke Indonesia pada abad ke-7 dan terus berkembang hingga kini. Ia telah memberi sumbangsih terhadap keanekaragaman kebudayaan Nusantara. Islam tidak saja hadir dalam tradisi agung (great tradition), bahkan memperkaya pluralitas dengan islamisasi kebudayaan dan pribumisasi Islam yang pada gilirannya banyak melahirkan tradisitardisi kecil (little tradition) Islam. Berbagai warna Islam-dari Aceh, Melayu, Jawa, Sunda, Sasak, Bugis, dan lainnya-riuh-rendah memberi corak keragaman tertentu, yang akibatnya dapat berwajah ambigu. Ambiguitas atau juga disebut ambivalensi adalah fungsi agama yang sudah diterima secara umum dari sudut pandang sosiologis.

Berbicara tentang pengaruh kultur dan adat lokal dalam kaitannya dengan agama, di sana terlihat adanya pergulatan untuk mengompromikan pesan religius keagamaan yang disinergikan dengan muatan lokal. Perjumpaan agama dengan budaya lokal itu mengambil banyak bentuk. Pertama, mengalami benturan (clash) yang sampai pada titik budaya setempat dihabisi dan diganti yang baru dengan Islamisasi misalnya, yang terjadi di Padang tempo dulu. Kedua, ada yang mengambil jalan akomodasi. Artinya, ada pertemuan saling mengisi dan tidak saling menjatuhkan. Islam diterima, tapi sebatas simboliknya. Adapun substansi seperti kepercayaan terhadap leluhur tetap dijaga. Ketiga, mengambil bentuk hibriditas. Artinya, mereka menerima agama, tapi separuhnya saja, sisanya tradisi setempat. Bentuk ini kemudian biasa dikenal dengan misalnya, Islam Jawa, Islam Banjar, Islam Sasak, dan sebagainya. ${ }^{9}$

\section{NEGOSIASI KREATIF ISLAM DAN BUDAYA LOKAL}

Dakwah yang dilakukan oleh para penyebar Islam awal ke Nusantara telah menunjukkan akomodasi yang kuat terhadap tradisi masyarakat setempat. Islam datang bukan sebagai ancaman, melainkan sahabat yang memainkan peran penting dalam transformasi kebudayaan. Hal ini menunjukkan bahwa karakter Islam di Indonesia yang berdialog dengan tradisi masyarakat sesungguhnya dibawa oleh para mubaligh India dalam penyebaran Islam awal di Indonesia. Para mubaligh India bersikap akomodatif terhadap tradisi masyarakat atau kultur masyarakat setempat, 
berbeda dengan mubaligh Arab yang puritan memberantas praktikpraktik lokal masyarakat. Karakter Islam yang dibawa orang-orang India inilah yang diteruskan Walisongo dalam dakwahnya di Jawa.

Proses dialog Islam dengan tradisi masyarakat diwujudkan dalam mekanisme proses kultural dalam menghadapi negosiasi lokal. Ia tidak diterima apa adanya ketika ditawar oleh khazanah lokal. Di sinilah, Islam dan tradisi masyarakat ditempatkan dalam posisinya yang sejajar untuk berdialog secara kreatif agar salah satunya tidak berada dalam posisi yang subordinat, yang berakibat pada sikap saling melemahkan. Perpaduan antara Islam dengan tradisi masyarakat ini adalah kekayaan tafsir lokal agar Islam tidak tampil hampa terhadap realitas yang sesungguhnya. Islam tidak harus dipersepsikan sebagai Islam yang ada di Arab, tetapi Islam mesti berdialog dengan tradisi masyarakat setempat. ${ }^{10}$

Tak pelak lagi, Islam sebagai agama yang menyebar ke seluruh penjuru dunia tampil secara kreatif berdialog dengan masyarakat setempat (lokal), berada dalam posisi yang menerima tradisi masyarakat, sekaligus memodifikasinya menjadi budaya baru yang dapat diterima oleh masyarakat setempat dan masih berada di dalam jalur Islam. Karena itu, kedatangan Islam merupakan pencerahan bagi kawasan Asia Tenggara, khususnya Indonesia, karena Islam sangat mendukung intelektualisme yang tidak terlihat pada masa Hindu-Budha. Bahkan, perpindahan masyarakat Indonesia dari sistem keagamaan dan budaya Hindu-Budha kepada Islam disamakan dengan perubahan pandangan Dunia Barat yang semula dipengaruhi mitologi Yunani kepada dunia nalar dan pencerahan. Rekonsiliasi Islam dengan tradisi masyarakat diyakini sebagai proses penerimaan yang dilakukan secara alamiah dan damai, tanpa penaklukan. Hal ini berbeda yang terjadi di Timur Tengah, di mana Islam disebarkan melalui proses kekuasaan politik.

Dialog Islam dengan tradisi ini dilakukan dalam semangat negosiasi. Negosisasi merupakan proses menafsirkan sesuatu yang hadir dan menafsirkan dirinya untuk mencari sesuatu yang baru yang dikenal dalam kebudayaan sebagai sesuatu yang hidup." Dalam konteks kultural, masyarakat memiliki kemampuan untuk bernegoisasi dengan caranya masingmasing. Pergulatan antara yang didatangi dan pendatang dalam bernegosiasi bukan didasarkan pada semangat saling mengubah karena kalau sudah saling mengubah bukan lagi negosiasi, melainkan hegemoni, bahkan represi. ${ }^{12}$ Negosiasi merupakan bagian dari transformasi kultural dalam gerak kebudayaan. Proses yang terjadi adalah proses kreatif dalam spirit 
kebudayaan sehingga baik pendatang maupun yang didatangi berada dalam struktur dan derajat yang sama.

Dalam konteks lain, negosiasi menjadi upaya untuk menghilangkan atau menurunkan nilai daya kekuatan tradisi pendatang. Negosiasi berfungsi untuk mengharmonikan yang asing dalam kearifan lokal. Melalui negosiasi, hal-hal baru dari luar wilayah tradisi tidak diterima begitu saja, namun dimodifikasi dari keasliannya, disesuaikan dengan daya terima tradisi. Keberadaan negosiasi tradisi merupakan hal yang alamiah. Tidak ada satu pun tradisi yang tidak memiliki negosiasi, yaitu kemampuan untuk mengajukan sesuatu yang menjadi milik lokal (sebagai asal) berdampingan atau memaknai sesuatu yang dari luar menjadi sesuatu yang baru (sebagai jadian kreatif). Negosiasi, dalam hal ini, bisa berarti sebagai daya arus balik dalam makna yang lebih lembut. Dalam proses negosiasi, ada upaya perbandingan dengan miliknya semula, ada proses pertimbangan pragmatis juga ideologis, dan ada niatan untuk menggunakannya secara baru. Pendeknya, negosiasi mengisyaratkan interpretasi kreatif dari pembeli atau pengguna. Negosiasi membuat serbuan dari luar akan dibaca lain, dan akan dimaknai secara berbeda. ${ }^{13}$

Negosiasi juga berhubungan dengan upaya untuk menghilangkan daya kekuatan tradisi pendatang. Definisi kedua ini berkait erat dengan asumsi bahwa setiap lokal didiami oleh kuasa politik atau kuasa kebenaran tertentu. Kedatangan tradisi pendatang sedikit banyak akan mengusik kuasa lokal itu. Oleh karena itu, secara alamiah pula, yang lokal akan menggunakan tradisi pendatang untuk mengartikulasikan kepentingannya, atau menggunakannya sebagai daya tawar baru untuk memperkuat posisinya di depan kekuatan-kekuatan dominatif dan hegemonik. Pada saat inilah, cara-cara pemaknaan baru-yang tidak sama dengan model pemaknaan di daerah asalnya-berlangsung. ${ }^{14}$

Negosiasi antara nilai agama dan budaya terjadi karena kedua nilai itu terdapat potensi yang relevan antara satu dengan lainnya. Potensi yang releven inilah yang menjaga kelangsungan hidup antara kedua variabel itu. Sebaliknya, apabila antara kedua variabel itu tidak memiliki potensi yang relevan, maka bentuk-bentuk antagonisme dalam masyarakat dengan segala implikasinya akan bermunculan. ${ }^{15}$

Tentu saja, dengan asumsi bahwa setiap tradisi dalam dirinya telah memiliki seruntut nilai tentang apa yang cocok bagi dirinya dan apa yang tidak cocok; atau apa yang diperlukan bagi perkembangan dan apa yang menghambat pertumbuhannya. Di sinilah letak makna penggunaan istilah resistensi. Resistensi digunakan untuk menakar sesuatu yang terjadi ketika 
dua tradisi yang berbeda melakukan proses saling tafsir, saling menyesuaikan, sampai akhirnya menghasilkan kesepakatan dalam satu pola komunikasi yang digunakan bersama. ${ }^{16}$

Dalam sejarah, proses negosiasi Islam dalam berdialog dengan tradisi masyarakat terjadi dalam skema mempengaruhi dan dipengaruhi. Islam mempengaruhi tradisi masyarakat, dan sebaliknya Islam dipengaruhi oleh tradisi masyarakat yang dibingkai dalam semangat rekonsiliasi. Proses timbal balik ini membawa nuansa yang harmonis dalam corak keislamanan Nusantara. Banyak bukti yang bisa ditunjukkan betapa Islam mampu bernegosiasi dengan tradisi masyarakat secara kreatif, tanpa penundukan.

Pertama, Islam mempengaruhi tradisi masyarakat atau kemampuan tradisi untuk menurunkan harga suatu hal agar ia dapat menjadi bagian dari dirinya. Dalam proses ini, yang terjadi adalah nilai-nilai Islam menjiwai tradisi masyarakat, baik dalam bentuk ritual, kesenian maupun normanorma. Dengan kata lain, Islam mengisi tata cara keagamaan masyarakat lokal. Hasil dari proses negosiasi yang seperti ini adalah lahirnya tradisi Islam lokal yang dipraktikkan di berbagai daerah.

Dalam bentuk norma-norma misalnya, di Minangkabau memiliki cerita mengenai negosiasi tradisi terhadap Islam. Ada adagium "adat basandi Syarak, Syarak basandi kitabullah” (adat berdasar pada agama, agama berdasar pada kitabullah) dan "Syarak mangato, adat mamakai" (agama merancang, adat menggunakan). Dalam adagium ini, jelas terlihat adat harus berdiri dan berkembang di atas dasar hukum agama, yakni alQur'an dan Hadits. Segala sesuatu yang bertentangan dengan agama Islam harus dibuang dari kehidupan adat atau budaya lokal masyarakat Minangkabau. Dalam pengertian ini, terlihat ada monopoli tafsir agama terhadap kehidupan adat Minangkabau. Bahkan, dapat dikatakan, bukan hanya sekadar monopoli, tetapi juga mendominasi semua pemahaman adat itu sendiri. ${ }^{17}$

Adagium ini konon hasil rekonsiliasi pasca-Perang Padri, abad ke-19. Perang Padri adalah pertarungan antara kaum Adat dan kaum Islam Puritan. Ketegasan paham Wahabi yang diimani oleh Haji Miskin, Haji Sumaniak, dan Haji Piobang membuat ketersinggungan kaum Adat, terlebih ketika Haji Miskin membakar Balai Adat masyarakat Pandai Sikek. Pada saat rekonsiliasi, mereka bersepakat untuk saling tawar-menawar (Islam tak harus menggantikan semua adat, dan adat tidak harus menolak semua ajaran Islam). Hasilnya adalah kesepakatan untuk membagi wilayah kebenaran dalam adagium "Syarak mamato, adat mamakai" itu. ${ }^{18}$ Proses 
negosiasi ini merupakan mekanisme alamiah yang terjadi ketika Islam berdialog dengan tradisi masyarakat.

Dari fenomena yang terjadi sejak awal abad ke-19 sampai sekarang, tampaknya adat dan agama Islam berhasil melalui proses penyesuaian yang saling bisa menerima. Toleransi Islam muncul seperti ditunjukkan oleh sikap ulama yang tidak mempersoalkan masalah harta pusaka tinggi dan perkawinan telah memperkukuh hubungan di antara kedua sistem nilai ini. Dalam bentuk ritual misalnya, kegiatan ritual yang dilaksanakan masyarakat diisi dengan ajaran-ajaran Islam. Tahlilan merupakan mekanisme Islam menawar tradisi masyarakat dengan cara mengisi acara-acara ritual masyarakat ketika menghadapi kematian. Jika dulu masyarakat sibuk dengan upacara-upacara adat terkait dengan kematian, maka setelah bernegosiasi dengan Islam; diisi dengan Tahlilan.

Kedua, ketika Islam dipengaruhi oleh tradisi masyarakat, maka yang terjadi adalah proses menerima tradisi masyarakat setempat untuk menundukkan pengaruh lain yang dianggap "berbeda" untuk menjadi bagian dari tradisi. Proses ini biasanya terjadi dalam arsitektur bangunan rumah ibadah dan beberapa perangkat di dalamnya. Misalnya, berpengaruhnya nuansa Sunda kepada Islam terlihat pada bangunan masjid. Di Sunda, pada awalnya, banyak masjid yang tidak mengikuti gaya arsitektur Timur Tengah, seperti dalam bentuk kubah, pintu masuk, dan mihrab, melainkan banyak bentuk masjid yang mengambil arsitektur setempat. Di antaranya, bentuk bangunan Masjid Agung Bandung zaman dulu yang terkenal dengan "bale nyungcung"-nya.

Dalam konteks negosiasi yang bersifat normatif, maka nilai-nilai negosiasi justru digunakan secara pragmatis. Sebagai contoh, agama mereka Islam, tetapi mereka tetap saja mempraktikkan ritual-ritual tradisinya. Dalam hal ini, tidak terjadi proses peleburan, melainkan berdiri sendiri dalam ranahnya masing-masing. Masyarakat adat yang beragama Islam di Kampung Naga dan Citorek misalnya menunjukkan bahwa agama dan tradisi diperlakukan oleh penganut masyarakat adat secara pragmatis, bukan ideologis. Pada masyarakat adat yang beragama Islam terjadi proses kolaborasi dua unsur, agama dan tradisi, yang mereka istilahkan sebagai "mendayung di antara dua perahu". Satu sisi, mereka mengimani akidah Islam, pada sisi lain mereka menggunakan tata cara bertahan hidup dengan bersumber pada tradisi. Cara berladang atau bersawah merupakan salah satu aktivitas yang merujuk pada tradisi yang didasarkan.pada perhitungan bintang-bintang yang merujuk pada dewa-dewa atau roh-roh. Hal ini tetap digunakan dengan argumen ajaran Islam tidak memberikan aturan dan 
petunjuk cara bercocok tanam, sekaligus juga bahwa cara tanam tradisi terbukti secara pragmatis menghasilkan panen yang lebih baik. ${ }^{19}$

\section{PRIBUMISASI ISLAM: ARTIKULASI ANTARA ISLAM DAN BUDAYA LOKAL}

Dialektika Islam dengan realitas kehidupan merupakan realitas yang terus-menerus menyertai agama ini sepanjang sejarahnya. Sejak awal kelahiran, Islam tumbuh dan berkembang dalam suatu kondisi yang tidak hampa budaya. Realitas kehidupan ini -diakui atau tidak-memiliki peran yang cukup signifikan dalam mengantarkan Islam menuju perkembangan yang aktual sehingga sampai pada peradaban yang mewakili dan diakui oleh masyarakat dunia.

Aktualisasi Islam dalam lintasan sejarah telah menjadikan Islam tidak dapat dilepaskan dari aspek lokalitas, mulai dari budaya Arab, Persi, Turki, India sampai Melayu. Masing-masing dengan karakteristiknya sendiri, tapi mencerminkan nilai-nilai ketauhidan sebagai unity yang mengikat secara kokoh satu sama lain. Islam yang beragam, tapi satu ini merupakan penerjemahan Islam universal ke dalam realitas kehidupan umat manusia.

Gagasan Islam pribumi, secara genealogis, diilhami oleh gagasan pribumisasi Islam yang pernah dilontarkan oleh Abdurrahman Wahid pada paruh akhir tahun 80-an. Dalam "pribumisasi Islam" tergambar Islam sebagai ajaran yang normatif berasal dari Tuhan yang diakomodasikan ke dalam kebudayaan yang berasal dari manusia tanpa kehilangan identitasnya masing-masing.

Bagi Abdurrrahman Wahid, Arabisasi atau proses mengidentifikasi diri dengan budaya Timur Tengah adalah tercerabutnya lokalitas dari akar budaya sendiri. Lebih jauh, Arabisasi belum tentu cocok dengan kebutuhan. Pribumisasi bukan sebagai upaya menghindari timbulnya perlawanan dari kekuatan-kekuatan budaya setempat, justru agar budaya itu tidak hilang. Karena itu, inti pribumisasi Islam adalah bukan untuk melakukan polarisasi antara agama dan budaya, karena polarisasi demikian memang tidak terhindarkan. ${ }^{20}$

Pribumisasi Islam mengambil semangat yang diajarkan oleh Walisongo dalam dakwahnya ke wilayah Nusantara sekitar abad ke-15 dan ke16 di pulau Jawa. Dalam konteks ini, Walisongo telah berhasil memasukkan nilai-nilai lokal dalam Islam yang khas Indonesia. Kreativitas ini melahirkan gugusan baru bagi nalar Islam Indonesia yang tidak harfiah dan tekstual meniru Islam di Arab. Tidak ada nalar Arabisasi yang melekat 
dalam penyebaran Islam awal di Nusantara. Hal ini tentu saja berbeda dengan sesuatu yang telah dilakukan pada masa selanjutnya, yakni abad ke-17 oleh Abdurrauf al-Sinkili dan Muhammad Yusuf al-Makasari yang lebih bercorak purifikasi dalam pembaruan Islam.

Walisongo justru mengakomodasikan Islam sebagai ajaran agama yang mengalami historisasi dengan kebudayaan. Misalnya, kegiatan yang dilakukan oleh Sunan Bonang dengan mengubah gamelan Jawa yang saat itu kental dengan estetika Hindu menjadi bernuansa zikir yang mendorong kecintaan pada kehidupan tarnsendental. Tembang "tombo Ati" adalah salah satu karyanya. Dalam pentas pewayangan, Sunan Bonang mengubah lakon dan memasukkan tafsir-tafsir khas Islam.

Oleh karenanya, 'Islam Pribumi' sebagai jawaban dari Islam otentik mengandaikan tiga hal. Pertama, 'Islam Pribumi' memiliki sifat kontekstual, yakni Islam dipahami sebagai ajaran yang terkait dengan konteks zaman dan tempat. Perubahan waktu dan perbedaan wilayah menjadi kunci untuk menginterpretasikan ajaran. Dengan demikian, Islam akan mengalami perubahan dan dinamika dalam merespons perubahan zaman. Kedua, 'Islam Pribumi' bersifat progresif, yakni kemajuan zaman bukan dipahami sebagai ancaman terhadap penyimpangan terhadap ajaran dasar agama (Islam), tetapi dilihat sebagai pemicu untuk melakukan respons kreatif secara intens. Ketiga, 'Islam Pribumi' memiliki karakter membebaskan. Dalam pengertian, Islam menjadi ajaran yang dapat menjawab problemproblem kemanusiaan secara universal tanpa melihat perbedaan agama dan etnik. Dengan demikian, Islam tidak kaku dan rigid dalam menghadapi realitas sosial masyarakat yang selalu berubah.

Dalam konteks inilah, 'Islam Pribumi' ingin membebaskan puritanisme, otentifikasi, dan segala bentuk pemurnian Islam, sekaligus menjaga kearifan lokal tanpa menghilangkan identitas normatif Islam. Karena itulah, 'Islam Pribumi' lebih berideologi kultural yang tersebar (spread cultural ideology), yang mempertimbangkan perbedaan lokalitas ketimbang ideologi kultural yang memusat, yang hanya mengakui ajaran agama tanpa interpretasi. Islam dapat tersebar di berbagai wilayah tanpa $\cdot$ merusak kultur lokal masyarakat setempat. Tidak akan ada lagi praktik-praktik radikalisme yang ditopang oleh paham-paham keagamaan ekstrem, yang selama ini menjadi ancaman bagi terciptanya perdamaian. ${ }^{21}$

Dengan mempertimbangkan situasi-situasi sosio-historis yang melingkupi nash al-Qur'an ketika turun, maka dapat disimpulkan bahwa terdapat hubungan dialektis antara teks al-Qur'an dan realitas budaya. Sifatnya yang selalu berdialektika dengan realitas itulah, maka tradisi 
keagamaan dapat berubah sesuai dengan konteks sosial dan kultural suatu masyarakat. Islam adalah agama sekaligus gerakan yang membuka dan memberi harapan kepada semua kelompok sosial, baik agama, kelas, etnik, dan gender yang hidup di dalam wilayah sosio-kultural tertentu. Hal itu untuk meneguhkan identifikasi diri mereka kepada lokalitasnya secara kritis, mengelola perbedaan-perbedaan yang muncul sebagai konsekuensi dan mengarahkan berbagai kelompok-kelompok yang berbeda tersebut. Pandangan ini dimaksudkan agar selalu melihat cita-cita yang lebih jauh untuk pemenuhan ketinggian harkat kemanusiaan mereka sendiri. ${ }^{22}$

Dalam aksinya, Islam pribumi selalu mempertimbangkan kebutuhankebutuhan lokal masyarakat dalam merumuskan hukum-hukum agama, tanpa mengubah hukum-hukum inti dalam agama. Sementara itu, ajaranajaran inti Islam itu dilahirkan di dalam kerangka untuk memberikan kontrol konstruktif terhadap penyimpangan-penyimpangan lokalitas yang terjadi. Tradisi lokal yang mempraktikkan pola-pola kehidupan zalim, hegemonik, tidak adil, maka Islam pribumi akan melancarkan kritiknya. Adapun terhadap tradisi lokal yang memberikan jaminan keadilan, dan kesejahteraan pada lingkungan masyarakatnya, maka Islam pribumi akan bertindak sangat apresiatif. Bahkan, tradisi lokal yang adi luhung (urf shahih) dalam pandangan Islam pribumi, memiliki semacam otoritas untuk men-takhsis sebuah teks nash. Sebagai ilustrasi, tradisi yang bersifat profan oleh para ulama kemudian diberi wewenang untuk men-takhsis teks yang dipandang berasal dari Tuhan..

Dengan platform pemikiran ini, maka wajar jika sejumlah para pakar ushul fiqh menyatakan bahwa mengetahui setting sosial historis Arab dari terbentuknya ketentuan agama seperti yang terpantul dalam teks suci menjadi sangat urgen dan signifikan. Al-Syathibi dalam al-Muwaffaqat $f i$ Ushul al-Syariah, menyatakan bahwa mengetahui kondisi sosial masyarakat Arab, sebagai lokus awal turunnya al-Qur'an dan situasi ketika ayat turun merupakan salah satu persyaratan yang mesti dimiliki oleh seorang mufasir. ${ }^{23}$

Dengan statemen ini, sesungguhnya al-Syathibi ingin mengatakan bahwa aspek-aspek yang perlu dipertimbangkan dalam menguak maksud teks bukan hanya dari sudut gramatika, melainkan juga harus mencakup pengetahuan tentang keadaan sosio-kultural yang hidup dalam masyarakat tatkala berlangsungnya pada era pewahyuan al-Qur'an. 


\section{PENUTUP}

Dakwah para penyebar Islam awal ke Nusantara menunjukkan akomodasi yang kuat terhadap tradisi lokal masyarakat setempat. Islam datang bukan sebagai ancaman, melainkan sahabat yang memainkan peran penting dalam transformasi kebudayaan. Hal ini menunjukkan bahwa karakter Islam Indonesia yang berdialog dengan tradisi masyarakat sesungguhnya dibawa oleh para mubaligh India dalam penyebaran Islam awal di Indonesia yang bersikap akomodatif terhadap tradisi masyarakat atau kultur masyarakat setempat. Hal ini berbeda dengan mubaligh Arab yang puritan dan memberantas praktik-praktik lokal masyarakat. Karakter Islam yang dibawa orang-orang India inilah yang diteruskan Walisongo dalam dakwahnya di Jawa.

Proses dialog Islam dengan tradisi masyarakat diwujudkan dalam mekanisme proses kultural dalam menghadapi negosiasi lokal. Ia tidak diterima apa adanya ketika ditawar oleh khazanah lokal. Islam dan tradisi masyarakat ditempatkan dalam posisinya yang sejajar untuk berdialog secara kreatif agar salah satunya tidak berada dalam posisi yang subordinat, yang berakibat pada sikap saling melemahkan. Perpaduan antara Islam dengan tradisi masyarakat ini adalah kekayaan tafsir lokal agar Islam tidak tampil hampa terhadap realitas yang sesungguhnya. Islam tidak harus dipersepsikan sebagai Islam yang ada di Arab, tetapi Islam mesti berdialog dengan tradisi masyarakat setempat.

Dakwah Walisongo justru mengakomodasikan Islam sebagai ajaran agama yang mengalami historisasi dengan kebudayaan. Misalnya, Sunan Bonang mengubah gamelan Jawa yang saat itu kental dengan estetika Hindu menjadi bernuansa zikir yang mendorong kecintaan pada kehidupan transendental. Tembang "tombo Ati” adalah salah satu karyanya. Lebih jauh dalam pentas pewayangan Sunan Bonang mengubah lakon dan memasukkan tafsir-tafsir khas Islam.

Oleh karenanya, 'Islam Pribumi' sebagai jawaban dari Islam otentik mengandaikan tiga hal. Pertama, 'Islam Pribumi' memiliki sifat kontekstual, yakni Islam dipahami sebagai ajaran yang terkait dengan konteks zaman dan tempat. Perubahan waktu dan perbedaan wilayah menjadi kunci untuk menginterpretasikan ajaran. Dengan demikian, Islam akan mengalami perubahan dan dinamika dalam merespons perubahan zaman. Kedua, 'Islam Pribumi' bersifat progresif, yakni kemajuan zaman bukan dipahami sebagai ancaman terhadap penyimpangan terhadap ajaran dasar agama (Islam), tetapi dilihat sebagai pemicu untuk melakukan respons kreatif 
secara intens. Ketiga, 'Islam Pribumi' memiliki karakter membebaskan. Islam menjadi ajaran yang dapat menjawab problem-problem kemanusiaan secara universal tanpa melihat perbedaan agama dan etnik. Islam tidak kaku dan rigid dalam menghadapi realitas sosial masyarakat yang selalu berubah.

Berdasarkan elaborasi tersebut, dapat disimpulkan bahwa kemampuan dakwah Islam untuk beradaptasi dengan budaya setempat, memudahkan dakwah Islam masuk ke lapisan paling bawah dari masyarakat. Islam sebagai agama yang menyebar ke seluruh penjuru dunia tampil secara kreatif berdialog dengan masyarakat setempat (lokal), berada dalam posisi yang menerima tradisi masyarakat, sekaligus memodifikasinya menjadi budaya baru yang dapat diterima oleh masyarakat setempat dan masih berada di dalam jalur Islam. Karena itu, kedatangan dakwah Islam merupakan pencerahan bagi kawasan Asia Tenggara, khususnya Indonesia.

\section{ENDNOTES}

1 Sebuah studi menarik berkaitan dengan tema ini, lihat Arbiyah Lubis, Pemikiran Muhammadiyah dan Muhammad Abduh, Suatu studi perbandingan (Jakarta: Bulan Bintang, 1993).

2 Taufik Abdullah, "Pengantar: Islam, Sejarah dan Masyarakat", dalam Taufik Abdullah (Ed.), Sejarah dan Masyarakat: Lintasan Historis Islam di Indonesia (Jakarta: Pustaka Firdaus, 1987), hal. 3.

${ }^{3}$ Muhammad Harfin Zuhdi, Parokialitas Adat Terhadap Pola Keberagamaan Komunitas Islam Wetu Telu di Bayan Lombok (Jakarta: Lemlit UIN Jakarta, 2009), hal. 111.

${ }^{4}$ Hasan Muarif Ambary, Menemukan Peradaban: Jejak Arkeologis dan Historis Islam Indonesia (Jakarta: Logos, 2001), hal. 251.

${ }^{5}$ Soerjanto Poespowardojo, "Pengertian Local Genius dan Relevansinya dalam Modernisasi" dalam Kepribadian Budaya Bangsa (local genius), Ayotrohaedi (Ed.) (Jakarta: Pustaka Jaya, 1986), hal. 28-38.

${ }^{6}$ Majma' al-Lughah al-'arabiyah (Beirut: Dar al-Fikr, 1972), hal. 286.

${ }^{7}$ Bassam Tibbi, Islam and Cultural Accommodation of Social Change (San Francisco: Westview Pres, 1991), hal. 1.

${ }^{8}$ Aziz al-Azmeh (Ed.), Islamic Law: Social and Historical Contexts (TTP: tp., 1988), hal. viii.

${ }^{9}$ Ahmad Baso, Plesetan Lokalitas: Politik Pribumisasi Islam (Jakarta: Desantara, 2002), hal. 7-8. Lihat juga "Tradisi Lokal dan Masa Depan agama" dalam Majalah Majemuk, No. 6, November-Desember 2003, hal. 3. 
Nunung Khoriyah: Dakwah dan Dimensi Akulturasi Budaya

${ }^{10}$ Khamami Zada, "Islam Pribumi: Mencari Wajah Islam Indonesia", dalam Tashwirul Afkar, Jumal Refleksi Pemikiran Keagamaan \& Kebudayaan, Edisi No. 14 tahun 2003.

11 Ibid.

${ }^{12}$ Lihat hasil Proceding Training Workshop Penguatan Kesetaraan, Toleransi, dan Perdamaian dalam topik Nilai-nilai Agama dan Budaya terhadap Perdamaian dalam presentasi Bisri Effendy, 30 Mei 2007.

${ }^{13}$ Bambang Q-Anees, "Daya Tawar Tradisi terhadap Pengaruh Luar" dalam www.gerbang.jabar.go.id.

$14 \mathrm{Jbid}$.

${ }^{15}$ Fachry Ali, Agama, Islam dan Pembangunan (Yogyakarta: PLP2M, 1985), hal. 76.

${ }^{16}$ Ahmad Ruchiyat, "Islam Sunda, Islam Tradisi atau Islamisasi Tradisi?" Pikiran Rakyat, 2 Januari 2003.

${ }^{17}$ Edy Utama, "Adat Basandi Syarak, Syarak Basandi Kitabullah", dalam Ahmad Baso, Plesetan Lokalitas: Politik Pribumisasi Islam (Jakarta: Desantara, 2002), hal. 124-125.

${ }^{18}$ Bambang Q-Anees, "Daya Tawar Tradisi terhadap Pengaruh Luar" dalam www.gerbang.jabar.go.id.

${ }^{19}$ Qomaruzzaman, "Menawarkan Diri Pada Syariat Islam", Pikiran Rakyat, 2 Januari 2003.

${ }^{20}$ Abdurrahman Wahid, Pergulatan Negara, Agama, dan Kebudayaan (Jakarta: Desantara, 2001), hal. 111.

${ }^{21}$ Khamami Zada, "Islam Pribumi...".

${ }^{22}$ M. Jadul Maula, "Syariat (Kebudayaan) Islam: Lokalitas dan Universalitas", makalah belajar bersama Islam Transformatif dan Toleran (Yogyakarta: LKiS, 2002).

${ }^{23}$ Al-Syatibi, al-Muwafaqat fi Ushul al-Syariah (Beirut: Dar al-Fikr, t.th), juz II, hal. 348.

\section{DAFTAR PUSTAKA}

Abdullah, Taufik. 1987. "Pengantar: Islam, Sejarah dan Masyarakat", dalam Taufik Abdullah (Ed.), Sejarah dan Masyarakat: Lintasan Historis Islam di Indoensia. Jakarta: Pustaka Firdaus.

Al-Azmeh, Aziz, (Ed.). 1988. Islamic Law: Social and Historical Context, tp: tkp.

Al-Sarakhsi, Muhammad ibn Ahmad. 1331. Al-Mabsut. Kairo: Matba'ah al-SI-Sa'adah. Al-Syatibi. t.th. al-Muwafaqat fi Ushul al-Syariah. Beirut: Dar al-Fikr.

Ambary, Hasan Muarif. 2001. Menemukan Peradaban: Jejak Arkeologis dan Historis Islam Indonesia. Jakarta: Logos.

Baso, Ahmad. 2002. Plesetan Lokalitas: Politik Pribumisasi Islam. Jakarta: Desantara.

2003. "Tradisi Lokal dan Masa Depan agama", dalam Majalah Majemuk, No. 6 November-Desember 2003. 
Bizawie, Zainul Milal. 2003. "Dialektika Tradisi Kultural: Pijakan Historis dan Antropologis Pribumisasi Islam", dalam Tashwirul Afkar, Edisi No. 14 tahun 2003.

Bruinessen, Martin van. 1999. "Global and Local in Indonesian Islam", dalam Southeast Asian Studies (Kyoto) vol. 37, No. 2, 1999. 1989. Kitab Kuning. Bandung: Mizan.

Lubis, Arbiyah. 1993. Pemikiran Muhammadiyah dan Muhammad Abduh, Suatu Studi Perbandingan. Jakarta: Bulan Bintang.

Lukito, Ratno. 1998. Pergumulan Antara Hukum Islam dan Hukum Adat. Jakarta: INIS.

Mahmasani, Subhi. 1952. Falsafat al-Tasyri' fi al-Islam. Beirut: Dar al-Kasysyaf linNasyr wa ltiba'ah wa at-Tauzi'.

Maula, M. Jadul. 2002. "Syariat (Kebudayaan) Islam: Lokalitas dan Universalitas" dalam Islam Transformatif dan Toleran. Yogyakarta: LKiS.

Poespowardojo, Soerjanto. 1986. "Pengertian Local Genius dan Relevansinya dalam Modernisasi", dalam Ayatrohaedi (Ed.). Kepribadian Budaya Bangsa (Local Genius). Jakarta: Pustaka Jaya.

Q-Anees, Bambang. 2009. "Daya Tawar Tradisi terhadap Pengaruh Luar", dalam www.gerbang.jabar.go.id, diakses tanggal 5 Juni 2010.

Tibbi, Bassam. 1991. Islam and Cultural Accommodation of Social Change. San Francisco: Westview Press.

Utama, Edy. 2002. "Adat Basandi Syarak, Syarak Basandi Kitabullah", dalam Ahmad Baso. Plesetan Lokalitas: Politik Pribumisasi Islam. Jakarta: Desantara.

Zada, Khamami. 2003."Islam Pribumi: Mencari Wajah Islam Indonesia" dalam Tashwirul Afkar, Jurnal Refleksi Pemikiran Keagamaan \& Kebudayaan, Edisi No. 14 tahun 2003.

Zuhdi, Muhammad Harfin. 2009. Parokialitas Adat Terhadap Pola Keberagamaan Komunitas Islam Wetu Telu di Bayan Lombok. Jakarta: Lemlit UIN Jakarta. 